\title{
The sim Gene of Escherichia coli Phage P1: Nucleotide Sequence and Purification of the Processed Protein
}

\author{
JULIA MAILLOU AND BRIGITTE DREISEIKELMANN' \\ Universität Bielefeld, Fakultät für Biologie, Lehrstuhl für Gentechnologie/Mikrobiologie, \\ Postfach 8640, 4800 Bielefeld, Federal Republic of Germany
}

Received October 12, 1989; accepted November 2, 1989

\begin{abstract}
The sim gene of bacteriophage P1 causes exclusion of a superinfecting P1 phage. We determined the nucleotide sequence of a 1.9-kb DNA fragment that, in plasmids, causes Sim phenotype. There are two open reading frames within this region for proteins of 82 and 259 amino acids. A 1.3-kb fragment containing the larger open reading frame was inserted into an expression vector. Induced cells carrying the hybrid plasmid, termed pBD5, were not infected by phage P1 and produced a 24-kDa protein and, to a smaller extent, a 25-kDa protein. The 24-kDa protein was purified. Comparison of its amino-terminal amino acid sequence with the nucleotide sequence indicated that it is processed from a precursor protein by removal of a hydrophobic leader peptide of 20 amino acids. In vivo processing depends on secA gene function and is necessary for Sim interference with P1 infection. The data are discussed with respect to the function of the sim gene in superinfection exclusion. (c) 1990 Academic Press, Inc.
\end{abstract}

\section{INTRODUCTION}

The sim gene of bacteriophage P1 was detected during attempts to clone the $c 1$ repressor gene (Devlin et al., 1982). Carried by a multicopy vector, the sim gene confers immunity to cells against infection with wildtype P1 and also $c 1, c 4$, and vir mutants. Therefore the extended immunity was called superimmunity $($ sim). The sim gene is localized on the P1 EcoRI-9 DNA fragment within the $i \mathrm{mml}$ region (Bächi and Arber, 1977; Yarmolinsky, 1987).

In a previous study (Kliem and Dreiseikelmann, 1989), we showed that cells carrying a multicopy plasmid with the sim gene (pMK4) are not really immune. Such cells are not lysogenized, can adsorb phage, but fail to synthesize phage-specific proteins following infection. The sim gene product does not interfere with the circularization and replication of phage P1 DNA or with the maturation or release of progeny phages. We concluded that the sim gene product blocks some early step following infection but not transformation, probably at a stage between adsorption of the phage and circularization of the injected DNA. Thus the sim gene does not confer immunity but rather a superinfection exclusion (Kliem and Dreiseikelmann, 1989). Genes which may have a similar function have been described in other bacteriophages, such as sieA in phage P22 (Susskind et al., 1974) and immT in phage T4 (Anderson and Eigner, 1971). The actual mechanism for superinfection exclusion is not yet known. The

\footnotetext{
${ }^{1}$ To whom requests for reprints should be addressed.
}

genes have not been sequenced and the gene products have not been purified or characterized. It has been speculated that the immT gene product may be a nuclease or may activate a periplasmic endonuclease of E. coli (Anderson and Eigner, 1971).

Plasmids with the cloned sim region of $\mathrm{P} 1$ express the Sim phenotype and produce three proteins in a minicell system (Kliem and Dreiseikelmann, 1989). We have now sequenced the sim region and have identified and purified a 24-kDa protein which seems to be the protein responsible for the superinfection exclusion.

\section{MATERIALS AND METHODS}

\section{Bacterial strains}

Escherichia coli JM101 $\Delta$ lac pro, thi, supE44 $\left[\mathrm{F}^{\prime}\right.$ traD36, proAB, lac $\left.\left.\right|^{\mid a Z} \mathrm{M} 15\right]$ was used for transformation with pUC 13 and $M 13 \mathrm{mp} 8$ and $M 13 \mathrm{mp} 9$ RF derivatives (Yanisch-Perron et al., 1985). E. coli C600 F-, thi1, thr-1, leuB61, lacY1, supE44, tonA21 was used for transformation with pJF118EH. Expression of genes from pPLc2819 derivatives was performed in $E$. coli K12 $\Delta$ H1 $\Delta$ trp, Smr, lacZ, $\Delta$ bio-uvrB, $\Delta$ trpEA2, $(\lambda$ Nam7-Nam53cl857 $\Delta \mathrm{H} 1$ ) (Remaut et al., 1981). E. coli MM52 $\mathrm{F}^{-}, \Delta$ (lac)U169, araD136, relA, rspL, thi, sec$A 51_{\text {ts }}$ was a gift from J. Tommassen (Oliver and Beckwith, 1981).

\section{DNA sequencing}

The nucleotide sequence was determined with the chain termination method (Sanger et al., 1977). Various 


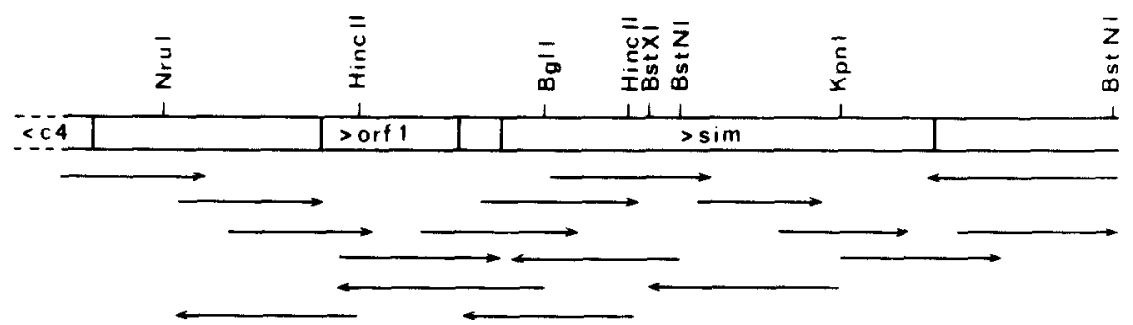

FIG. 1. Strategy for determination of the nucleotide sequence of a 1.9-kb DNA fragment from the sim region. Sequence of the upper strand was mainly determined with the aid of deletion derivatives produced by limited digestion with exonuclease III and VII (Yanisch-Perron et al., 1985). The lower strand was sequenced after subcloning of different DNA restriction fragments.

DNA inserts were ligated into M13mp8 and mp9 RFDNA (Messing and Vieira, 1982). DNA synthesis at the M13 single strand was performed with a T7 DNA polymerase system purchased from U.S. Biochemical Corporation (Tabor and Richardson, 1987).

\section{SDS-PAGE}

Polyacrylamide slab gels (14 or $17.5 \%$ acrylamide, $1 \mathrm{~mm}$ thick, $8 \mathrm{~cm}$ long) were prepared as described (Laemmli, 1970). Electrophoresis was performed for about $2 \mathrm{hr}$ at $20 \mathrm{~mA}$. Gels were stained with Coomassie brilliant blue $\mathrm{G}-250$. The protein marker mix from Pharmacia contained phosphorylase b (mol wt 94,000 ), BSA (mol wt 67,000), ovalbumin (mol wt 43,000 ), carboxyanhydrase (mol wt 30,000 ), trypsin inhibitor (mol wt 20,100), $\alpha$-lactoalbumin (mol wt 14,400).

\section{Isolation of the 24-kDa protein}

Growth of the cells and induction. $\mathrm{K} 12 \Delta \mathrm{H} 1 \Delta$ trp (pBD5) was grown in 1 liter TBY medium at $30^{\circ}$ to a density of $3 \times 10^{8}$ cells $/ \mathrm{ml}$. Temperature was shifted to $42^{\circ}$ for $20 \mathrm{~min}$ and incubation was continued for $2 \mathrm{hr}$ at $37^{\circ}$. Cells were harvested by centrifugation. The cells (wet wt $4 \mathrm{~g}$ ) were resuspended in $5 \mathrm{ml}$ cooled buffer A (20 mM Tris- $\mathrm{HCl}, \mathrm{pH} 7.8,40 \mathrm{mM} \mathrm{NaCl}, 0.1$ mM EDTA, $7 \mathrm{~m} M \beta$-mercaptoethanol).

Crude extract. Cells were disrupted by a French Press at a pressure of $18,000 \mathrm{psi}$. The lysate was centrifuged for $1 \mathrm{hr}$ at 30,000 rpm in a TST55.5 rotor (Kontron) at $4^{\circ}$.

Streptomycin sulfate step. Streptomycin sulfate ( $30 \%$ solution) was slowly added to the crude extract to a final concentration of $3 \%$. The mixture was stirred for $30 \mathrm{~min}$ at $0^{\circ}$ and centrifuged for $30 \mathrm{~min}$ at $8000 \mathrm{rpm}$ in a $\mathrm{A} 8.24$ rotor (Kontron).

Ammonium sulfate precipitation. Solid ammonium sulfate was added to the supernatant to $60 \%$ saturation. The mixture was stirred in ice for $30 \mathrm{~min}$. After 2 hr at $0^{\circ}$ the precipitate was collected by centrifugation for $30 \mathrm{~min}$ at $8000 \mathrm{rpm}$ in a $\mathrm{A} 8.24$ rotor. The precipitate was resuspended in $4 \mathrm{ml}$ buffer $B$ ( $20 \mathrm{mM}$ sodium phosphate, $\mathrm{pH} 7.8,0.1 \mathrm{mM}$ EDTA, $7 \mathrm{mM} \beta$-mercaptoethanol) and dialyzed for $2 \mathrm{hr}$ against the same buffer.

Hydroxyapatite chromatography. The dialyzed fraction was loaded onto a hydroxyapatite column (diameter $1.5 \mathrm{~cm}$, height $2.5 \mathrm{~cm}$ ), previously equilibrated with buffer $\mathrm{B}$. The column was washed until the $\mathrm{OD}_{280}$ was 0.05 . Adsorbed proteins were eluted with a linear gradient $(100 \mathrm{ml})$ of 20 to $200 \mathrm{mM}$ sodium phosphate in buffer $B$. The flow rate was $10 \mathrm{ml} / \mathrm{hr}$. Fractions of $1 \mathrm{ml}$ were collected. The 24-kDa protein was identified by SDS-PAGE. Fractions containing this protein, which eluted between 40 and $80 \mathrm{mM}$ sodium phosphate, were pooled and dialyzed against buffer $A$.

Mono $Q$ ion-exchange chromatography. The dialyzed sample was loaded on an equilibrated Mono $Q$ column (HR5/5, Pharmacia) and chromatographed by FPLC. The $24-\mathrm{kDa}$ protein was eluted at a $\mathrm{NaCl}$ concentration of 300 to $400 \mathrm{mM} \mathrm{NaCl}$ with a linear gradient from 0.05 to $1 \mathrm{M} \mathrm{NaCl}$ in buffer $\mathrm{A}$.

Protein sequencing. The protein was transferred to a membrane (Immobilon, Millipore) and the amino-terminal amino acids were determined with an automated protein sequencer (Knauer model 810, Berlin). Separation of the PTH amino acids was performed on-line on a PTH-C ${ }_{18}$ column (Applied Biosystems, $220 \times 2.1 \mathrm{~mm}$ ) at a flow rate of $0.24 \mathrm{ml} / \mathrm{min}$ using a sodium acetate/ THF/acetonitrile eluent system as described (Hunkapiller, 1985).

\section{RESULTS}

\section{Nucleotide sequence analysis of the sim region}

In a preceding paper (Kliem and Dreiseikelmann. 1989) we have shown that the sim gene product interferes with $\mathrm{P} 1$ infection by blocking an early step following phage adsorption. In minicells three proteins with apparent molecular weights of about 25, 24, and 15 $\mathrm{kDa}$ were detected originating from the 2.1-kb EcoRIPvull sim region. In order to sequence the gene(s) re- 


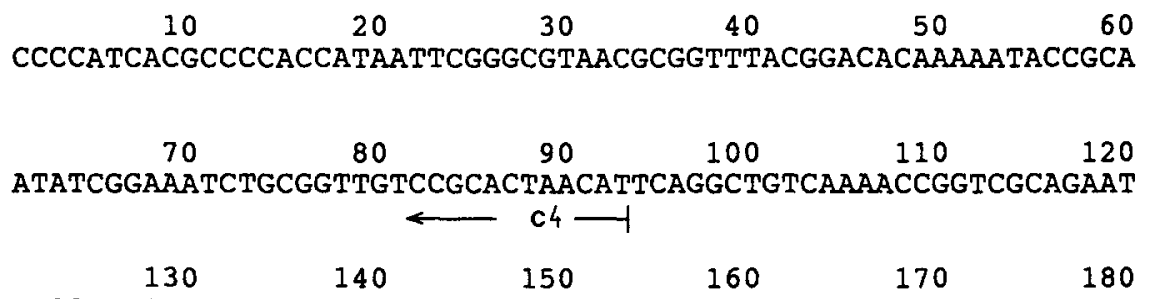

TTGCTACGACGGTGGAACTATAAGCCTGAACGATTAAAAGGTCAATATGATGCGAAAAGA

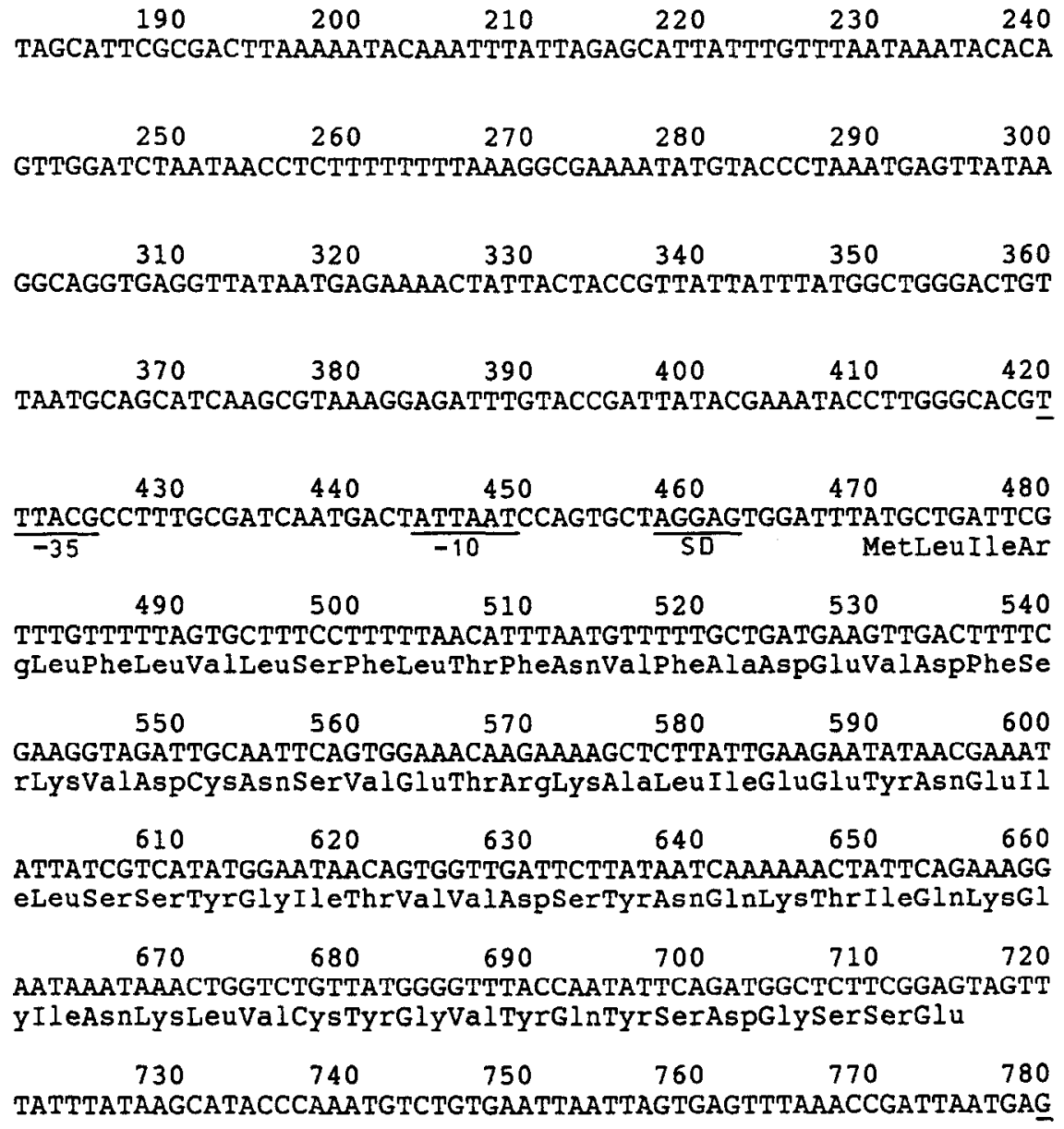

FIG. 2. Nucleotide sequence of a 1.9-kb DNA fragment of the sim region. The two open reading trames which could encode proteins are shown with their deduced amino acid sequences. A possible promoter and the Shine-Dalgarno (SD) sequences are marked.

sponsible for the superinfection exclusion phenotype within this region, we inserted various subfragments of the ECoRI-Pvull fragment into M13mp8 and mp9 RFDNA (Bächi and Arber, 1977). The sequencing strategy is summarized in Fig. 1. The nucleotide sequence determined by dideoxy sequencing is shown in Fig. 2.

At the $5^{\prime}$ end of the nucleotide sequence there is part of the $c 4$ gene reading from right to left (position 93-1). The sequence agrees with published data (Baumstark and Scott, 1987). Two other open reading frames with the opposite orientation as the c4 gene (positions 1524-1381 and 1272-1132), and one with the same orientation (position 290-445), are evident. However these lack apparent transcriptional (promoter) and translational (ribosome binding site) signals. Two open reading frames which could possibly encode proteins are indicated along with their amino acid sequences in Fig. 2. One open reading frame starts at position 470 and ends at position 715. Upstream of it there is a possible promoter with a typical -10 and -35 sequence and a Shine-Dalgarno consensus sequence. The open reading frame would encode a protein of 82 amino acids. The second open reading frame (position 7761547) has two start codons (position 776 and 791) but 
$\begin{array}{llllll}790 & 800 & 810 & 820 & 830 & 840\end{array}$ TGAATGGAAAATGAAATTATTTAATGTAATAACATTTTGTTGTGCTATTTTTGCTGGAAG $\overline{S D}$ MetLysLeuPheAsnValileThrPheCysCysAlaIlePheAlaglyse

$\begin{array}{llllll}850 & 860 & 870 & 880 & 890 & 900\end{array}$ CGCGATAGCTGATAATAAATTGCCAGATTGGCTTTCTACCTCAAAGAAAGATTATGATTT rAlaI I eAlaAspAsnLysLeuProAspTrpLeuSerThrSerLysLysAspTyrAspLe $\begin{array}{llllll}910 & 920 & 930 & 940 & 950 & 960\end{array}$ AGTAAGGGCATTCTATTTGTCTGGATTTGCTTCGAAAGCAATGAACAATCAATTTGGTTA uValArgAlaPheTYrLeuSerGlYPheAlaSerLysAlaMetAsnAsnGInPheGIYTy

$970 \quad 980 \quad 990 \quad 1000 \quad 1010 \quad 1020$ TCATTTGCCATCTGAGTTGGTTAATGATTTTAAAGATAATGAATTTGCTGCTCAGGAAAA rHisLeuProSerGluLeuValAsnAspPheLysAspAsnGluPheAlaAlaGlnGIuLy

$1030 \quad 1040 \quad 1050 \quad 1060 \quad 1070 \quad 1080$
ATGGAACACAATTCCAATTGTGTATGGTGAAATAAAATCCATAAGAATGGTGAATAATAA sTrpAsnThrI leProI leval TyrGlyGluI leLysSerIleArgMetValAsnAsnLy
1090
1100
1110
1120
1130
1140

ACCAATTGTAGAATTATTTACTCCAGGGGAAAATGCAACGCCTATAAATTATATCAAATT sProI leValGI ULeuPheThrProGIyGluAsnAlaThrProIleAsnTyrI leLysIe 1150 $1160 \quad 1170$ 1180 1190 1200 GAAAATATTGGATTCAAAGCAAGACTCTCTGTTAAAACTAAAAAAAGGGGATGATATATA uLys I l eLeuAspSerLysG I AAspSerLeuLeuLYsLeuLYSLYSGIYAspAspI I TY 1210 1220 1230 1240 1250 1260 TGCAGTGTGCTCCGGTGCTAATTTTAGCTTAGTGCCAATTCTGAGCAACTGCACTCCAGC IAlavalCys SerGlyAlaAsnPheserLeuvalProI leLeuSerAsnCysThrProAI 1270 1280 1290 1300 1310 1320 AACAGACGTCATTGATGCTGCACTCTCTTTTTCTGGTGAATATATGTTCCCTGCTTTTGA aThrAspval I eAspAlaAlaLeuSerPheSerGlyGluTyrMetPheProAlapheAs

1330

1340

1350

1360

1370

1380 TTCTTTTTCACCTACTAAGCAAAACGTCAAATATATATTCACAAATCAAGATCCTGTTCA pSerPheSerProThrLysGInAsnValLysTyrI lePheThrAsnglnAspProValGl
1390
1400
1410
1420
1430
1440

GATGATGAATTTTATAGGGTACCTATCCTTAGTCGATACAACGAAGGATAAGAATAAAAT nMetMetAsnPheI leGlyTyrLeuSerLeuValAspThrThrLysAspLysAsnLysMe $\begin{array}{llllll}1450 & 1460 & 1470 & 1480 & 1490 & 1500\end{array}$ GGATATGGTTCGTAAGTGTACGCCTTGGAAGCCGGAATGTTCACAACAATTCGTTGATGT tAspMetValArgLysCysThrProTrpLys ProGluCys SerGInGinPheValAspVa $\begin{array}{llllll}1510 & 1520 & 1530 & 1540 & 1550 & 1560\end{array}$ AATGGAAGGATTTGATAGCATCATGTATAAATATGAGGGAGAATTTAAAAACTACATAGA IMetGluGlyPheAspSerI leMetTyrLysTyrGluGlyGluPheLysAsnTyrIleGl
1570
1580
1590
1600
1610
1620

ATTAAAATAGTGTTTGAAAGGATAGTCAATTTAAGTTTTAACACCAACGCCCATTAAAGG uLeuLys
1630
1640
1650
1660
1670
1680

GCTTTTATTGTTTTACTCAAAACAACCTGATTAGTGTATAACCATATCATATCCCTCATT

$\begin{array}{cccccc}1690 & 1700 & 1710 & 1720 & 1730 & 1740\end{array}$

CCACCTACACTGATTACCCCCAGACAACAATATTCCTACTCAATGAACAAATGACTACTC

$1750 \quad 1760 \quad 1770 \quad 1780 \quad 1790 \quad 1800$
GTAGAATCGGTTAACACACCAGATTCTACGAGGTTTCAATGACACCACGACAATTACTCG

$\begin{array}{llllll}1810 & 1820 & 1830 & 1840 & 1850 & 1860\end{array}$
AAGACGTCAAAACCCGCTTCACACCTTTGATTGCGGATGAACCGGCCTTACTGGAATCCC
1870
1880
1890
1900

TGCTAAGAAAAGCATTGGGAACCTACCAGGATAGGGCGGG

FIG. 2-Continued 


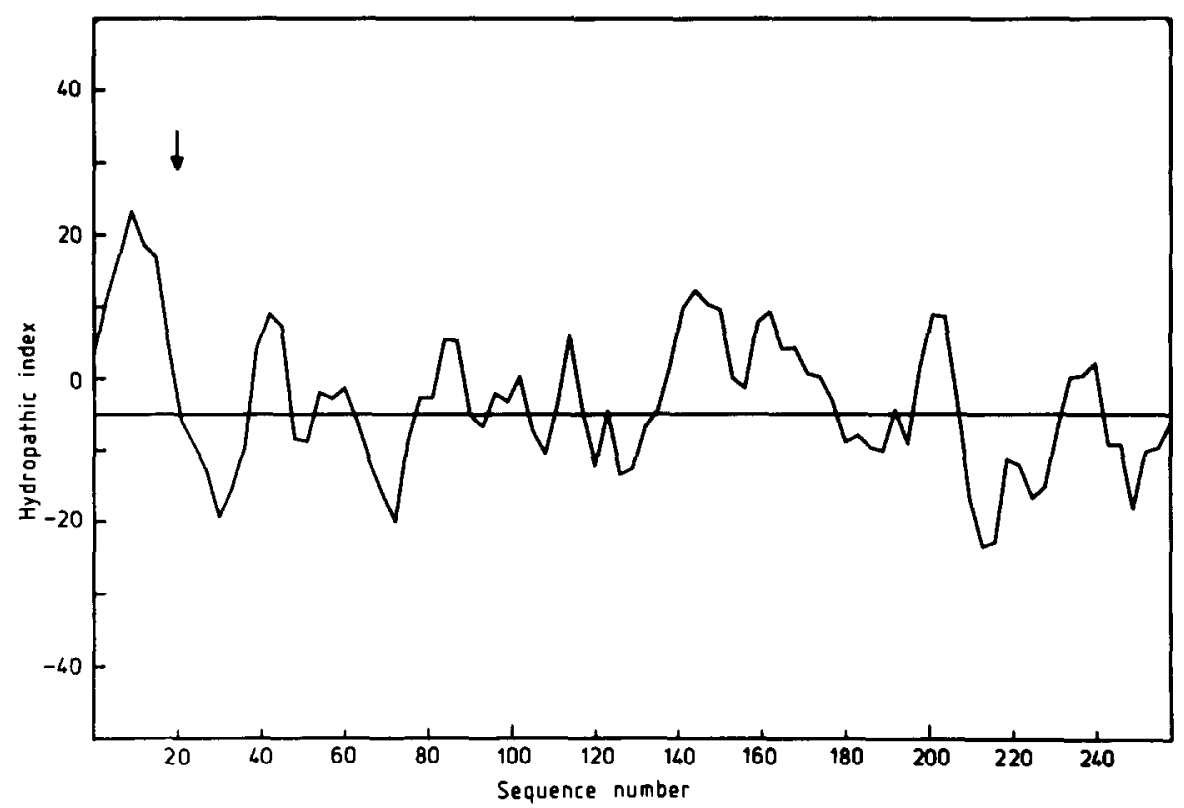

Fig. 3. Hydropathic plot of the hypothetical Sim protein. The hydropathic plot was performed as described at a span setting of nine residues (Kyte and Doolittle, 1982).

only the $A \cup G$ at 791 has a possible ribosome binding site, allowing for a protein of 259 amino acids. A promoter is not evident. At the end of the open reading frame there is an inverted repeat followed by numerous thymine residues, which may represent a transcriptional terminator (position 1606-1634).

The possible protein encoded by the latter open reading frame would have a molecular weight of 29,326 Da and may represent the 25-kDa protein previously described (Kliem and Dreiseikelmann, 1989). The apparent discrepancy between the molecular weight deduced from the nucleotide sequence and that determined by SDS-PAGE will be considered in the discussion. For simplicity we will maintain the 24- and $25-\mathrm{kDa}$ protein nomenclature. A hydropathic plot shows that the 25$\mathrm{kDa}$ protein resembles a precursor protein with a hydrophobic leader sequence (Fig. 3). The amino-terminal amino acid sequence has the characteristics of a hydrophobic signal sequence (Oliver, 1985): (i) the length of the hydrophobic region is 20 amino acids, (ii) the protein begins with a positively charged region (Lys 2, Asn 5), (iii) there are two helix destabilizing amino acids at the distal site of the hydrophobic amino acid sequence (Gly 16 and Ser 17), (iv) the hydrophobic leader ends with the characteristic Ala-X-Ala sequence (Ala 18-lle 19-Ala $20)$. This suggests that the $24-\mathrm{kDa}$ protein observed in minicells (Kliem and Dreiseikelmann, 1989) may originate by processing of the 25-kDa protein.

\section{Isolation of the 24-kDa protein and determination of the amino-terminal amino acid sequence}

The following experiments demonstrate that the protein predicted from the nucleotide sequence is indeed synthesized in vivo as a precursor $(25 \mathrm{kDa})$ and is subsequently processed by proteolytic removal of a leader peptide to give the mature protein $(24 \mathrm{kDa})$.

The 1320- and 1300-bp EcoRI-HindIII DNA frag ments from pMK4d5 and pMK4d6 (Kliem and Dreiseikelmann, 1989) were inserted into the expression vector pPLc2819 (Remaut et al., 1981). Cells carrying hybrid plasmid pBD4 or pBD5 were induced for $2 \mathrm{hr}$ at $42^{\circ}$. Total protein from uninduced and induced cells was separated by SDS-PAGE. Overproduction of the 24- and the 25-kDa protein was observed (Fig. 4). Generally the $25-\mathrm{kD}$ a protein was less abundant than the $24-k D a$ protein. The $24-k D a$ protein was purified from induced cells as described under Materials and Methods (Fig. 5). To eliminate minor contaminants from fractions obtained after chromatography on a Mono $Q$ column these were further purified by electrophoresis on a preparative SDS polyacrylamide gel. The protein purified in this way gave a single band on a silver-stained SDS-PAGE loaded with $2 \mu \mathrm{g}$ of protein (data not shown).

The purified protein was subjected to automated protein sequencing. The sequence of the first 15 amino acids was identical to that predicted from the nucleotide sequence analysis, but started with the aspartic acid residue at nucleotide position 851 corresponding to Asp 21. From this we conclude that the 24-kDa protein is the processed form of a precursor protein. The cleavage site is between Ala 20 and Asp 21. Processing would remove a hydrophobic leader sequence of 20 amino acids (see Fig. 3). 


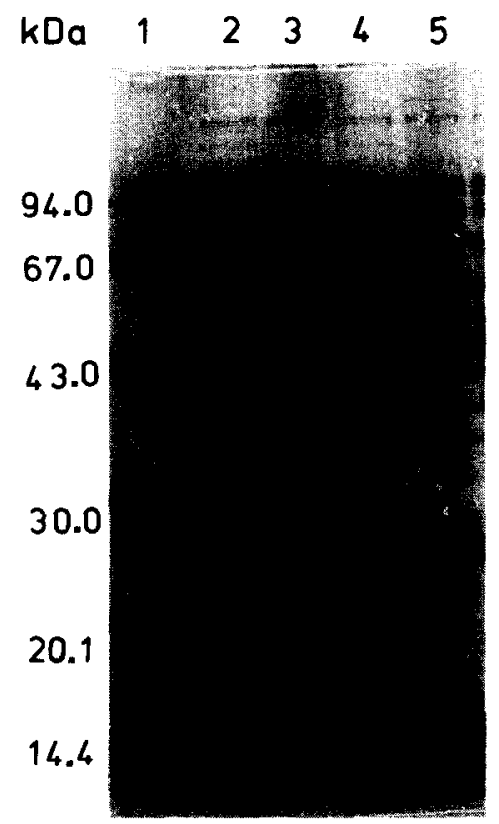

Fig. 4. Overproduction of a 25- and 24-kDa protein in cells with plasmids pBD4 and pBD5. SDS polyacrylamide gel (14\%) of total protein from uninduced and induced cells. 1, marker proteins; 2, pBD4 without induction; 3, pBD4 with thermoinduction; 4, pBD5 without induction; 5 , pBD5 with thermoinduction.

\section{Processing of the 25-kDa protein is essential for its biological activity}

The 1300-bp DNA fragment containing the sim gene was inserted into the expression vector $\mathrm{pJF} 118 \mathrm{EH}$ with the tac promoter (Fürste et al., 1986). The hybrid plasmid, called pBD6, was introduced into E. coli MM52

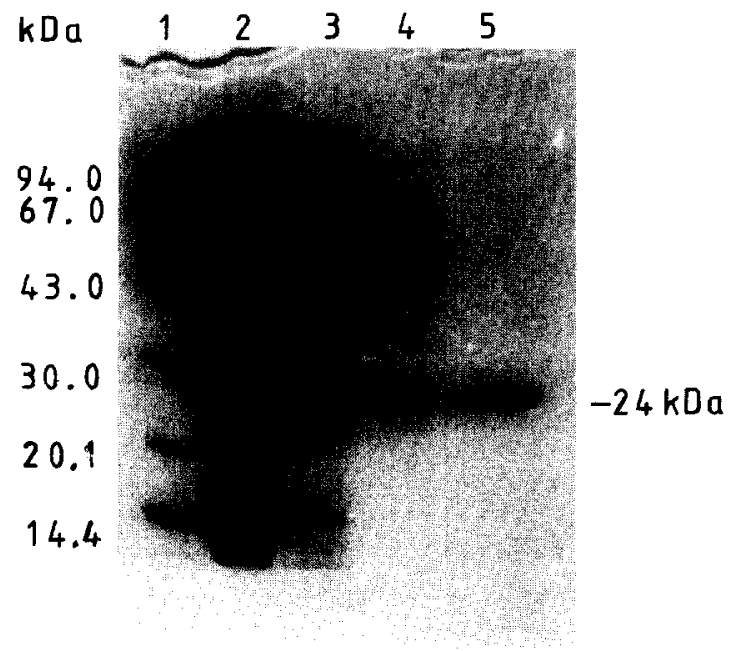

FIG. 5. Purification of the $24-k D a$ protein. SDS polyacrylamide gel (17.5\%) with samples from crude extract (lane 2), ammonium sulfate precipitation (lane 3), hydroxyapatite fractions (lane 4), Mono $Q$ fractions (lane 5), marker proteins (lane 1).

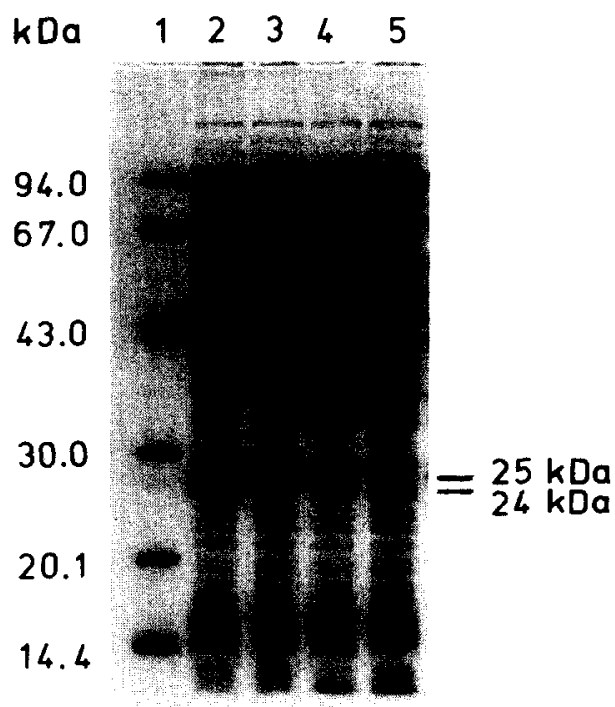

Fig. 6. Processing of the Sim protein in $s c c A_{t s}$ sells. SDS poly acrylamide gel (14\%) with total protein from Escherichia coli secA pBD6. Molecular weight standards (lane 1); $30^{\circ}$, induction with IPTG (lane 2); $30^{\circ}$, uninduced cells (lane 3 ); $42^{\circ}$, induction with IPTG (lane 4); $42^{\circ}$, uninduced cells (lane 5).

$\sec A_{t s}$. At the nonpermissive temperature, the precursor forms of many membrane proteins and periplasmic proteins are accumulated in $\sec _{\mathrm{ts}}$ cells (Oliver and Beckwith, 1981). Cells with pBD6 were induced with 4 $\mathrm{mMIPTG}$ at 30 and $42^{\circ}$, and total protein was analyzed by SDS-PAGE (Fig. 6). After induction at $30^{\circ}$ the 24$\mathrm{kDa}$ protein is the predominant protein as compared to the $25-\mathrm{kDa}$ precursor. However, at $42^{\circ}$ the reverse is observed-the 25-kDa protein accumulates and the processed form can hardly be detected. Therefore we conclude that the $25-\mathrm{kDa}$ protein precursor is converted into the $24-\mathrm{kDa}$ mature protein by proteolytic cleavage of the leader sequence depending on the secA function.

Induced $\operatorname{secA}_{\mathrm{ts}}$ cells with pBD6 are not infected by $\mathrm{P} 1$ at the permissive temperature of $30^{\circ}$, but they are susceptible to the phage at the nonpermissive temperature of $42^{\circ}$ (Table 1). Thus the secA-dependent processing of the Sim protein is necessary for its function in blocking phage infection.

TABLE 1

Infection of E. coli secA ts Cells with Phage P1

\begin{tabular}{ccc}
\hline & \multicolumn{2}{c}{ Infective centers (ml) } \\
\cline { 2 - 3 } Strain & $30^{\circ}$ & $42^{\circ}$ \\
\hline MM52 pJF118 & $\begin{array}{c}3 \times 10^{9} \\
<10^{2}\end{array}$ & $\begin{array}{r}8 \times 10^{10} \\
5 \times 10^{10}\end{array}$ \\
\hline
\end{tabular}




\section{In vitro properties of the Sim protein}

It has been suggested for phage T4 that the immT gene product may be a nuclease (Anderson and Eigner, 1971). The purified Sim protein (Mono $Q$ fraction) had no detectable nuclease activity when tested with linear double-stranded DNA under a variety of conditions. For T4 it has recently been described (Obringer, 1988 ) that the sp gene product, which is encoded by a gene in the vicinity of the $i m m T$ gene, directly interacts with the phage tail. Phage infectivity is abolished by destruction of components of the injection apparatus. Incubation of purified Sim protein with phage P1 (15 to $60 \mathrm{~min}$ at room temperature; $20 \mathrm{mM}$ Tris- $\mathrm{HCl}, \mathrm{pH} 7.5$, $10 \mathrm{mM} \mathrm{NaCl}, 5 \mathrm{mM} \mathrm{MgCl}, 5 \mathrm{mMCaCl}_{2}$ ) did not reduce the efficiency of plating of the lysate. This result suggests that the purified protein does not directly interact with some tail protein to inhibit the contact of phage particles with the receptor or the induction of a membrane channel for the injection of the DNA. The negative result does not exclude such interactions in vivo, which may need other factors.

\section{DISCUSSION}

The nucleotide sequence of the sim region contains two open reading frames. The smaller one is preceded by a typical promoter region and a Shine-Dalgarno sequence. Downstream of the smaller open reading frame a larger one follows with its own Shine-Dalgarno sequence. It is likely that both genes are transcribed from the same promoter as an operon. Plasmids pBD4 and pBD5 still express the sim phenotype, although the first open reading frame is deleted in these plasmids. This implies that the gene product of the small reading frame is not essential for the superinfection exclusion phenotype. However, deletion of a Kpnl-HindIII DNA fragment from plasmid pBD5, which removes about one-fifth of the distal part of the gene, resulted in the loss of the sim phenotype (data not shown). The product of the larger reading frame must therefore be the Sim protein. Its overproduction and processing in cells with pBD5 suffices to exclude infecting $P 1$ phages from the cell.

The mechanism by which the Sim protein abolishes infection of cells by phage P1 is still not clear. We can now add the observation that the Sim protein may be a periplasmic or membrane-associated protein to our earlier results showing that the Sim protein blocks an early stage of $\mathrm{P} 1$ infection (Kliem and Dreiseikelmann, 1989). The following facts support this hypothesis: (i) the Sim protein is synthesized as a precursor with a hydrophobic leader sequence of 20 amino acid residues, (ii) only the processed form of the protein is biologically active, (iii) processing of the precursor is secA dependent, since overproduction of the precursor is reduced at the nonpermissive temperature compared to the mature form at the permissive temperature. This is also observed for several other periplasmic and membrane proteins which are synthesized at a reduced level in secA cells and accumulate the precursor forms (Liss and Oliver, 1986; Strauch et al., 1986).

The Sim protein is a rather hydrophobic protein which may account for the discrepancy between the apparent molecular weight as determined by SDSPAGE (25 kDa, sometimes up to $27 \mathrm{kDa}$ depending on the choice of marker proteins) and the predicted molecular weight deduced from the nucleotide sequence (29.3 kDa). In the literature one can find contrasting statements on the mobility of hydrophobic proteins during electrophoresis. There are indications for lower (Garten et al., 1975) as well as for higher mobilities (Heller, 1978) than expected after heating in detergent. The Sim protein, which was always incubated for $5 \mathrm{~min}$ at $100^{\circ}$ before electrophoresis, had a higher mobility than expected.

Since the Sim protein was isolated from a soluble fraction (see Materials and Methods), we suggest that the major portion of the protein may be localized in the periplasmic space. However, we cannot exclude the possibility that part of the protein may also be localized in the membrane. If the Sim protein is a membrane protein, the membrane association would probably be a specific one, so that overproduction of the protein would lead to a saturation of potential membrane binding sites. Further studies employing isolated membranes and osmotic shock proteins from Sim-producing cells are necessary to decide the localization of the Sim protein and to eludicate the mechanism of superinfection exclusion.

\section{ACKNOWLEDGMENTS}

We thank Prof. Dr. Tschesche and his co-workers for sequencing of the protein and U. Beigel for excellent technical assistance. J. Maillou was supported by a grant from the European Community.

\section{REFERENCES}

ANDERSON, C. W., and EIGNER, J. (1971). Breakdown and exclusion of superinfecting T-even bacteriophages in Escherichia coli. J. Virol. 8, 869-886.

BÄCHI, B., and ARBER, W. (1977). Physical mapping of Bg/ll, BamHI, EcoRl, Hindlll and $P$ stl restriction fragments of bacteriophage $P 1$ DNA. Mol. Gen. Genet. 153, 311-324.

BAUMSTARK, B., and ScotT, J. R. (1987). The $c 4$ gene of phage P1. Virology 156, 197-203.

DEVLIN, B. H., BAumsiakK, B. R., and ScotT, J. R. (1982). Superimmunity: Characterization of a new gene in the immunity region of $\mathrm{P} 1$. Virology 120, 360-375.

Fürste, J. P., Pansegrau, W., Frank, R., Blöcker, H., Scholz, P., BAGDASARIAN, M., and LANKA, E. (1986). Molecular cloning of the 
plasmid RP4 primase region in a multi-host-range tacP expression vector. Gene 48, 119-131.

GARTEN, W., HindenNACH, I., and HenNING, U. (1975). The major proteins of the Escherichia coli outer cell envelope membrane: Characterization of proteins $\|^{*}$ and III, comparison of all proteins. Eur. J. Biochem. 59, 215-221.

HELLER, K. B. (1978). Apparent molecular weights of a heat-modifiable protein from the outer membrane of Escherichia coli in gels with different acrylamide concentrations I. Racteriol. 134, 1181 1183.

Hunkapillar, M. W. (1985). In "User Bulletin Protein Sequencer," Applied Biosystems Issue No. 14.

KLIEM, M., and DREISEIKELMANN, B. (1989). The superimmunity gene sim of bacteriophage $\mathrm{P} 1$ causes superinfection exclusion. Virology $171,350-355$

KYTE, J., and DOOLITTLE, R. F. (1982). A simple method for displaying the hydrophobic character of a protein. J. Mol. Biol. 157, 105-132.

LAEMMLI, U. K. (1970). Cleavage of structural proteins during the assembly of the head of bacteriophage T4. Nature $227,680-685$.

LISS, L. R., and OLIVER, D. B. (1986). Effects of secA mutations on the synthesis and secretion of proteins in Escherichia coli. Evidence for a major export system for cell envelope proteins. J. Biol. Chem. 261, 2299-2303.

MESSING, J., and VIEIRA, J. (1982). A new pair of M13 vectors for selection either DNA strand of double-digest restriction fragments. Gene 19, 269-276.
Obringer, J. W. (1988). The functions of the T4 immunity and spackle genes in genetic exclusion. Genet. Res. 52, 81-90.

OLIVER, D. B. (1985). Protein secretion in Escherichia coli. Annu. Rev. Microbiol. 39, 615-648.

Oliver, D. B., and BeCKWITH, J. (1981). E. coli mutant pleiotropically defective in the export of secreted proteins. Cel/ 25, 765-772.

Remaut, E., Stanssens, P., and Fiers, W. (1981). Plasmid vectors for high-efficiency expression by the $p_{1}$ promoter of coliphage lambda Gene 15, 81-93.

SANGER, F., NICKLEN, S., and COULSON, A. R. (1977). DNA sequencing with chain-termination inhibitors. Proc. Natl. Acad. Sci. USA 74, 5463-5467

Strauch, K. L., Kumamoto, I., and BeckWITH, J. (1986). Does secA mediate coupling between secretion and translation in Escherichia coli? J. Bacteriol. 166, 505-512.

SUSSKIND, M. M., BOTSTEIN, D., and WRIGHT, A. (1974). Superinfection exclusion by P22 prophage in lysogens of Salmonella thyphimurium. III. Failure of superinfecting DNA to enter sieA ${ }^{+}$lysogens. Virology 62, 350-366.

TABOR, S., and RICHARDSON, C. C. (1987). DNA sequence analysis with a modified bacteriophage T7 DNA polymerase. Proc. Natl. Acad. Sci. USA 84, 4767-4771.

YANISCH-PERRON, C., VIEIRA, J., and MESSING, J. (1985). Improved M13 phage cloning vectors and host strains: Nucleotide sequences of the M13mp 18 and pUC19 vectors. Gene 33, 103-119.

YARMOLINSKY, M. (1987). Bacteriophage P1. In "Genetic Maps, 1987" (S. J. O'Brien, Ed.), Vol. 4, pp. 38-47. Cold Spring Harbor Laboratory, Cold Spring Harbor, NY. 